\title{
Recent Dutch-language Publications
}

\author{
Harry A. Poeze \\ KITLV/Royal Netherlands Institute of Southeast Asian and Caribbean Studies \\ Poeze@kitlv.nl
}

Matthias van Rossum, Werkers van de wereld. Globalisering, arbeid en interculturele ontmoeting tussen Aziatische en Europese zeelieden in dienst van de VOC, 16oo-180o. Hilversum: Verloren, 2014, 448 pp. ISBN 978908704419o. Price: EUR 39.00 (hardback).

This study of the Asian workers with the voc was the author's $\mathrm{PhD}$ dissertation at the Vrije Universiteit in 2013. Hitherto it was assumed that such intercultural meetings were only exceptions, but serious consideration of the subject was absent. This was also caused by the voc board in Holland that expressly forbade the employment of Asian workers. Thus they were hardly employed on the ships that sailed from Holland to the Indies and back. The voc officials in Batavia, however, ignored the Amsterdam directive, and simply did not report on a substantial scale their recruitment of Asian personnel to be employed in the intra-Asian shipping. There was hardly a choice-European workers were not available due to a high death-rate and desertion. For the voc this intra-Asian shipping was four to five times as voluminous as the travels to Europe. It made the voc the strongest power in the splintered Asia trade, although voc's share did not even reach $20 \%$.

Van Rossum has collected new material on this Asian trade, and summarized these in tables and graphs. As to the Asian workers, they were recruited in China, Bengal, Java, and many more places in the East Indies. Sometimes they were contracted as a group under a leader, but most of them were individual contract partners. Next to them the voc also employed, for instance in the harbours, slaves and daily labourers. They worked alongside their European colleagues, with certainly a number of Indo-Europeans also active. The voc understandably had great trouble categorizing these diverse workers. The effort had its basis not in racial discrimination, argues Van Rossum, but rather in ethnocentric administrative requirements. Evidence of this includes the fact that the wages were equal for all the seamen, whether European or Asian. In secondary benefits, the Asians even had a slight edge. Working with the voc

(C) HARRY A. POEZE, 2014 | DOI: 10.1163/22134379-17004013

This is an open access article distributed under the terms of the Creative Commons

Attribution-Noncommercial 3.0 Unported (CC-BY-NC 3.0) License. 
came close to contract labour, as seamen had no freedom to abrogate their contract. Heavy penalties were set for desertion or similar infringements. Life as a sailor was tough. Control and discipline were upheld with violence, and redress was difficult to find. Capital punishment was a common phenomenon. However, there were some positive features, too. There was considerable upward mobility, from ordinary seaman to higher ranks, when a network of patronage could be tapped. But this venue was open only to Europeans, as knowledge of the Dutch language was a prerequisite. Those who did not meet these conditions had to find a way to make life on board endurable. Day-to-day life was not a segregated affair. Across racial barriers there was contact, as well as shared pastimes like drinking and smoking. It even went as far as multiracial sexual relationships. These last cases were brought before a voc court, and when considered proven ended in the death penalty. Even a case of sodomy with a dog ended in a death sentence-for man and dog. Notwithstanding the authoritarian regime on a ship conflicts and protests concerning wages and benefits were regular and brought before voc authorities, who at times had to give in. Other more radical protests resulted in absence and desertion, or ultimately in strikes, murder, and mutiny - with a rising number of these initiated by Asians.

Van Rossum's study also contributes to a better theoretical understanding of the globalisation of labour. Regarding Asia, its beginnings have to be advanced by more than a century. Striking is the equivalence of Asian and European personnel. The rather automatic backward transposition of nineteenth century inequality is proven to be wrong. Van Rossum's study is a pioneering effort that unveils a hitherto unknown world. He has meticulously searched in the vast voc archives for signs of life of the Asian workers at the bottom of the hierarchy—and he gives ample details from these archives to bring to life these multinational workers. He also contributes to a rethinking of concepts like globalisation and labour relations, and supplies in his tables and graphs the results of new painstaking and time-consuming research.

Dienke Hondius, Nancy Jouwe, Dineke Stam, Jennifer Tosch and Annemarie de Wildt, Gids slavernijverleden/Slavery heritage guide Amsterdam. Arnhem: LM Publishers, 2014, 138 pp. ISBN 9789460223686. Price: EUR 12.50 (paperback).

This bilingual guide (Dutch and English) aims to give information about the Dutch role in international slavery, in particular about the role played by Amsterdam. Amsterdam was closely involved in the slave trade and in the exploitation of African slaves in the plantations of Dutch-governed Surinam. In Amsterdam slavery left its marks on politics, economics, art, architecture, culture, 
and religion. The Amsterdam elite, in its stately mansions, in no small measure based its riches on the profits from the trade and exploitation of slaves. The authors have identified more than a hundred relevant places and buildings, added new facts and evidence, and tell the stories. The connections concern trade and profit, with a gallery of prominent inhabitants and their living space. Another focus is on the limited number of coloured people who settled in the city, and of whom only a few traces remain in the archives and the graveyardsas long ago as 1629 a black servant was buried. There was also resistance to slavery and a not so strong abolitionist movement. Museums and archives, and recent memorials are also listed. All objects are described, and with the help of a map a tour might be made. There are visible remains like gable stones and yawners, and specific buildings, once the offices and warehouses of the WestIndische and Oost-Indische Compagnie, but of most of the listed places it is the story behind the walls, taken down in this guide, that shows the close involvement. The authors do not only look at the Atlantic slave trade, but also explicitly looks at the East Indian slavery and its Amsterdam vestiges - a rather neglected subject, but of considerable magnitude. The guide, in full colour, has hundreds of illustrations. A bibliography and index add to its value.

Jan Veenendaal, Aziatische kunst en de Nederlandse smaak. Zwolle: Waanders, Den Haag: Gemeentemuseum, 2014, 232 pp. ISBN 9789491196799. Price: EUR 39.95 (hardback).

Jan Veenendaal, Asian Art and Dutch Taste. Zwolle: Waanders, Den Haag: Gemeentemuseum, 2014, 232 pp. ISBN 9789462620001. Price: EUR 39.95 (hardback).

This book, also available in English translation, accompanies an exhibition in the Gemeentemuseum The Hague, and was arranged by Jan Veenendaal, a prominent collector and expert on Asian applied art of the voc period. He supplemented his own objects with loans from many collections. The focus of the exhibition is on the twofold interaction between eastern produce and western demand. The first resulted in an adaptation of Asian applied art to European taste, even on the basis of express guidelines from the far-away buyer, with the export of millions of pieces of chinaware as the outstanding example. In another variant Europeans, Indo-Europeans, and Asians themselves, living in Asia, inspired the Asian craftsmen to produce goods suited to the Europeaninfluenced taste of these settlers. Veenendaal has organised his book in 23 chapters, most devoted to a particular craftsmanship: chinaware, furniture, and 
other objects made from precious woods, for a great part made in Ceylon and India, silver, gold, and copper objects, Javanese kris (daggers), chintzes, and batiks, and Balinese wood-carving. Separately, subjects like the Dutch stay in Deshima, specific objects and festivities, the prominent Batavia jeweller Van Arcken and the almost forgotten Indo-European painter Jan Daniël Beijnon (1830-1877) are discussed, without explaining the ratio behind these choices. The chapters attest to the author's expertise, and are of high scholarly quality. Of course, the 322 illustrations are the result of the excellent photography for which the publisher is renowned. Not only objects are included but also quite a lot of contemporary paintings and drawings in which these objects of art figured.

G.J. Schutte (ed.), Seer teder beminde Heer Vader en Vrouw Moeder. Brieven van de Groninger Familie Fockens in de Oost, 1748-1783. Uitgegeven door G.J. Schutte. Hilversum: Verloren, 2014, 442 pp. ISBN 9789087044237. Price: EUR 39 (paperback).

Six members of the Groningen elite Fockens family—father, three sons, and two daughters - went to the East Indies. Father Nathan (1695-1780), a lawyer, accompanied his son Willem (1727-1779) on the arduous journey in 1746, but was back within the year, when expectations of a prosperous career in Batavia did not materialise. Willem, however, never returned home, and embarked on a career that brought him to the Moluccas as a governor, and ultimately the title of Edeleer, member of the Raad van Indië. In 1758 two younger brothers, Berend (1734-1784) and Jacob (1736-1777), went abroad, and in no small measure thanks to their brother's patronage found a place in the voc elite. Their sister Anna Wendelina (1741-1765) made the trip with them, with the intention of finding a wealthy spouse - and within weeks of her arrival this was accomplished. She died young, like so many Dutchmen in the tropical colony. Helena (1746-1801) in 1779 followed her military husband. The letters that were sent to their parents by the five Fockens children, as well as children-in-law, in the period $1748-1783,138$ in total, have been collected in this volume. They are kept in the archive of the Nederduits Hervormde Kerk in Pretoria, South Africa. G.J. Schutte, retired professor at the Amsterdam Vrije Universiteit, and a specialist in Indonesian and South African colonial history discovered these documents and has worked on an edited publication for fifteen years. This has been done meticulously and admirably, with a 9o-page introduction, genealogical information (25 pages), 1439 annotations to the introduction and letters, bibliography, and an index of personal names. In this respect a minor critique 
might be the lack of a subject index, to access the scattered information in the letters on many subjects. The letters are retained in their original spelling and do not make the easiest reading, although no specialist knowledge is needed to understand them. Many letters follow the conventions of the time and are rather formal and formulaic. An exception here are the candid letters by Anna Wendelina. The collection is unique as to its quantity. It shows, for instance, how family, marriage, and friendship translated into patronage, nepotism, and favoritism in Groningen and the Indies. The opinion on the indigenous population was rather negative, and slavery was taken for granted. They are given only scant attention. The European background of the Fockens family members was never forgotten. In this respect Schutte cautiously questions the image in recent studies of Batavia as a mixed-blood society.

M. Ferares, De revolutie die verboden werd; Indonesië 1945-1949. Amsterdam: Abigador, 2014, 290 pp. ISBN 9789079319022. Price: EUR 29.50 (paperback) (to order from the publisher: m.ferares@kpnmail.nl).

Maurice Ferares (1922) has a history of seventy years of political involvement in the radical-socialist movement. In the forties and fifties he was prominent in Trotskyite organisations. In its periodicals he published on Indonesia, with a special interest in Tan Malaka, then considered as close to the Trotskyite political thought. This specific interest in Indonesia remained, and now, at last, he published his De revolutie die verboden werd, a manuscript that has already circulated in a smaller circle for a number of years. It is a polemical report, in a sharply critical tone, first on the development of a communist movement in colonial Indonesia. This Partai Kommunis Indonesia (PKI) affiliated with the Moscow-dominated Communist International (Comintern), and was soon the victim of the capricious Soviet policies, dictated by intra-Russian controversies, in particular the Stalin-Trotsky feud. In 1926-1927 in China and Indonesia this resulted in disastrous collapses, all, in Ferares' opinion, the result of Stalinist bureaucratic dictatorship. Blame for the failures was laid with Trotsky, and the PKI, reduced to an underground group, remained faithful to Moscow, with Muso as its leader in exile. Ferares includes a number of interesting documents from the Comintern archives, hitherto unpublished, in the 38 appendixes of his book. After the hundred or so pages on pre-1942 developments - the period given in the title is somewhat misleading-Ferares turns to the post-war developments. The Dutch social-democrats in power betrayed their lofty ideals of a new relationship with Indonesia, by opposing the Republic of Indonesia. And by sending troops, the Dutch communists (CPN) supported this recolonisa- 
tion until 1948, as did the Perhimpoenan Indonesia, the influential Indonesian students organisation in the Netherlands. Their stand was copied by the PKI in Indonesia, which followed a moderate course, cooperated in bourgeoisdominated governments, and supported the Linggajati Agreement, that contravened the ideals of the proclamation of independence of 17 August 1945. Ferares emphasises that the choice for a revolutionary mobilisation of poor peasants and workers was not made, causing the failure of a socialist revolution. Notwithstanding his sympathy for Tan Malaka, he also reproaches him for not having made this choice. The PKI policies changed when Moscow in 1948 engaged itself in a Cold War with the West. Muso returned from Moscow and promoted a radical course which led to the Madiun Insurrection. Ferares' analysis of this revolt is rather shaky, and omits available evidence. In all, this book is a polemical, partisan account. For the insiders, it opens up a number of new sources and some new vistas, especially in the appendixes included. Unfortunately references are rather scanty and inconsistent, and too many errors mar this monograph.

Hugo Jan van der Kaay and Dirk Gerrit Ponsen, Planters School Vereniging, Brastagi, 1926-1942. Een andere kijk dan die van Rudy Kousbroek. Zoetermeer: Free Musketeers, 2013, 133 pp. ISBN 9789048430482. Price: EUR 16.95 (paperback).

In 1926 the great Deli companies opened the Planters School Vereniging (PSV) in Brastagi, situated at an altitude of 1400 metres, 60 kilometres from Medan. It offered school—primary and secondary—and boarding for the children of their European employees. It grew gradually to more than 200 pupils. After the Japanese occupied Sumatra in 1942 it served as an internment camp for women and children till the end of 1944. Its background made it a unique educational institute in the Indies. One of its pupils was Rudy Kousbroek (1929-2010), the well-known author. In his book Negri pan erkomst (1995) he related the memoirs of his youth, prompted also by a journey back to the region of his youth. Kousbroek paints his years at PSV (1939-1942) in the blackest of colours, even calling his Japanese internment a relief after the PSV tyranny. His views on the Japanese camps were widely criticised by former inmates and the subject of a rather unpalatable polemic. Now, two former class-mates have taken up the gauntlet as to Kousbroek's picture of PSV. They contradict almost all of his observations, most of them rather convincingly. They go as far as speculate about Kousbroek's psychological make-up that might explain his distortions, and should have better not done so. The polemic fills about twenty pages, and 
is followed by a hundred pages, with hundreds of illustrations on the PSV. It is an exhaustive list of all the aspects of PSV-organisation, situation, buildings, school, staff, curriculum, highlights—-that certainly deserve to be recorded.

J.J.G. Sijatauw, De Japanse bezetting van Nederlands-Indië 1942-1945. Een gezamenlijke ervaring van duizenden. Voorburg: U2pi, 2013, 233 Pp. ISBN 9789087593971. Price: EUR 19.95 (paperback).

Professor Sijatauw, of Ambonese descent, was born in Bandung (West Java) in 1923, studied law and was a lecturer in international law in the Us and the Netherlands. About ten years ago he finished the writing of a book, now published as De Japanse bezetting van Nederlands-Indië 1942-1945. Memoirs of Dutchmen on the occupation abound, especially about the grim experiences in internment camps. On the contrary, reminiscences of Indonesians are rare. Sijatauw thus helps to fill a lacuna. He wants to combine personal experiences and views with an overview of the Japanese occupation. Thus, he comments on the inglorious defeat of the Dutch colonial army and the peculiar position of Ambonese soldiers in this army. Their loyalty towards the Dutch met with a lot of Japanese suspicion, which also extended to their families. Interesting are Sijatauw's observations on his work as a typist/translator in the head office of the Mining Service, after it was taken over by the Japanese. He was also involved in embryonic resistance activities, and, with his family members, in the struggle for survival in dire economic circumstances. His survey of the general course of events during 1942-1945 touches on a number of relevant developments, but mostly brief and without opening new vistas - and with too many repetitions (for instance, six pages of text are included twice).

Ilse Akkermans, Bestemming Soerabaja. Een verzwegen verleden in NederlandsIndië. Amsterdam: Cossee, 2014, 272 pp. ISBN 978905936479o. Price: EUR 19.90 (paperback).

Writings by Dutch military veterans of the decolonisation war in Indonesia (1945-1949) are abundant. They number in the hundreds. Still, there continue to appear new titles. Worth of mention among these is Bestemming Soerabaja, written and edited by journalist Ilse Akkermans (1972), on the basis of letters and diaries written on the spot by her father Harry Akkermans (1927), and supplemented by extensive recent interviews. Akkermans enlisted voluntarily in 1945 as a marine in the new Mariniersbrigade. He was trained in the us 
and arrived in Indonesia in December 1945. He was deployed in and around Surabaya and involved in heavy fighting against the Indonesian adversary, with all the atrocities commonly connected with a guerrilla war. He was demobilised in January 1948. Only in the last ten years his daughter recorded his Indonesian experiences into a readable, coherent story, put in the context of the decolonisation, and also with keen attention for his family, pious Catholic village dwellers in Brabant province. It all results in a publication that is of interest beyond the circle of veterans and their offspring.

Dane Beerling, Petjok, een taal met geschiedenis, met veel verhalen en woordenlijst. Amsterdam: Dane Beerling, 2013, 178 pp. No ISBN. Price: EU R 15.00 (paperback) (to order from: www.tjaberawit.nl, or by payment into the bank account NL42ING B0004580865 of D. Beerling).

Dane Beerling (1934) is an indefatigable promoter of Indo European culture, as is proven by his website www.tjaberawit.nl, a long list of publications and numerous public appearances. Not a minor part of his efforts concern Petjok, the language that developed from Batavian and Indies Dutch into a distinct language, combining Dutch words with Malay grammar. It was looked upon with disdain, and its spread was counteracted in the Indies. Written Petjok was almost absent. After 1945, in exile, Petjok was often the subject of misinterpretation. Thanks to a number of devoted authors and researchers, among them Tjalie Robinson, in the first place, and Dane Beerling, Petjok now slowly is becoming acknowledged as a separate language. In his Petjok Beerling brings together a number of his writings. They are often polemical, and suffer partly from a lack of structure and from repetitiveness. Anecdotes and stories adorn his writings. More material is collected in twenty pages of Petjok stories. At last, and probably the most valuable part of the book, more than seventy pages offer a Petjok dictionary, with a lot of additional information supplied in the entries.

Pamela Pattynama, Bitterzoet Indië. Herinnering en nostalgie in literatuur, foto's en films. Amsterdam: Prometheus/Bert Bakker, 2014, $270+8$ pp. ISBN 9789035132955. Price: EUR 24.95 (paperback).

Pamela Pattynama (1948) was a professor in colonial and postcolonial literary and cultural history at the University of Amsterdam from 2005 till 2013. In these years she published a plethora of articles of which a number have been reworked, combined and expanded to be included as a chapter in Bitterzoet 
Indië, as part of a solid monograph on the relationship between remembrance and reality. In a variety of formats, including literature, films, photos, websites and drama, the colonial Indies are given their own particular content in post-colonial Netherlands by the 300,00o refugees that fled war and revolution, and also the 130,000 soldiers who fought a decolonisation war from 1945 till 1949. The author's perspective is foremost that of the second-generation Indo-Europeans, who searched for identity in 'a battlefield where emotion and controversy reign supreme'. In the 1970 s memories were adapted to fit in the need for identity and identification. Nostalgia for the colonial past, or tempo doeloe, became prominent-a modern, multifaceted and contradictory concept, complicating rather than facilitating understanding.

After introducing her subject Pattynama in six chapters discusses in six case studies striking examples of the changes in historical views, prompted by contemporary discussions about background and identity. The nyai, the 'coloured' concubine of a Dutchmen in the Indies, the mother of Indo-European children, was long seen as the wicked seducer, and mostly obliterated from family history. This has all changed for a romantic image, in which she has become the valued bond between the Indies and the Indies community in the Netherlands. Adaptation of Multatuli's Max Havelaar in drama, musical, and comic book form has turned it from a critical treatise that never questioned the colonial relationship into an anticolonial plea. Such a change in focus, although not that radical, also is clear in the film Oeroeg (1993), based on Hella Haasse's novel (1948). Far more explicit references to the independence struggle are included, and the role of Indo-Europeans is not as subordinate as in the book. Two more films by Orlow Seunke and Marion Bloem are more explicit on the Indo-European past, although still within the nostalgia framework. Pattynama concludes that these films are not depicting a historical past but are concerned with the Netherlands nowadays.

Quite a few Dutch documentary films have tried to come to grips with identity and identification and look back at the complicated past and contribute to the historiography on decolonisation and migration. It's striking that almost universally the nostalgic view of an idyllic past is retained. In these films history is shaped, rather than told. Family photographs are the last subject of Pattynama's analysis. They became the instrument with which the Indo-Europeans asserted their identity, as the photographs documented their own life-style and are part of their collective memory. As a member of an extended Indo family Pattynama here and elsewhere could draw from her own reminiscences. She concludes that the precarious relation between nostalgia, guilt, and other emotions causes tensions. The Indies are now a something for everybody, with discussions now mainly on and by photographs and films. But surely, the Indies 
are and will remain very much alive. In all, this is a stimulating book, that peels away layers to reach obscured truths. With 23 pages of notes and an extensive bibliography it is also scholarly up to the standards, except for the regrettable and rather stupid absence of an index.

Gerard A. Persoon, Floor Hendriks, Iris van Genuchten and Anna de Keijzer (eds), Grenzeloos. Antropologie in Leiden; 136 jaar Volkenkunde, 85 jaar dispuut WDO, 57 jaar instituut CA-OS, 20 jaar Itiwana. Leiden: Instituut voor Culturele Antropologie en Ontwikkelingssociologie, 2013, 220 pp. ISBN 9789082040944. Price EUR 15 (hardcover) (to order from the publisher, Wassenaarseweg 52, 2333 AK Leiden).

Half a century ago the Faculty of Social Sciences at Leiden University was created, and the Institute for Cultural Anthropology and Development Sociology became an important part of it. The commemoration now has given the Institute the impetus to publish a solid book on the University and anthropology. The closely affiliated debating club WDO (founded 1928) and student's association Ittiwana (1993) also have their place in this book. The book-in oblong format, well-produced and copiously illustrated in colour-is packed with information. It contains, as one expects, the history of the Institute, as well as its preceding years centred around the chair of ethnology, with a lot of emphasis on Indonesia, starting with P.J. Veth in 1877 . He has had until now about 40 successors, who are all given a page with a portrait and a short biography. Indonesia is still one of the main subjects of interest, but does not dominate any more, while the focus has changed. A lot of interviews with staff and students from the past and the present, about their experiences with anthropology in Leiden and accounts of their fieldwork, add flavour to the book. In this way it has become an excellent present to relations and visitors and a dazzling introduction for prospective students. 